\title{
Impact of Exposure to Media Devices in Early Childhood on the Later Language Development: Cohort Study
}

\author{
YoonKyoung Lee ${ }^{\mathrm{a}}$, Yun-Mi Shin ${ }^{\mathrm{b}}$, Jieun Choi ${ }^{\mathrm{c}}$, Hee Jeong Yoo ${ }^{\mathrm{d}}$, Eun Jin Park \\ ${ }^{a}$ Division of Speech Pathology and Audiology, Hallym University, Chunchon, Korea \\ ${ }^{b}$ Deptartment of Psychiatry, Ajou University School of Medicine, Suwon, Korea \\ 'Department of Speech-Language Pathology and Audiology, Graduate School of Hallym University, Chuncheon, Korea \\ ${ }^{d}$ Department of Psychiatry, Seoul National University Bundang Hospital, Seoul National University College of Medicine, Seongnam, Korea \\ ${ }^{e}$ Department of Psychiatry, Inje University Ilsan Paik Hospital, Goyang, Korea
}

\author{
Correspondence: Yun-Mi Shin, MD \\ Deptartment of Psychiatry, Ajou University School \\ of Medicine, Suwon, 16499, Korea \\ Tel: +82-31-219-5180 \\ Fax: +82-31-219-5179 \\ E-mail: ymshin@ajou.ac.kr
}

Received: July 20, 2018

Revised: August 17, 2018

Accepted: September 7, 2018

This research was supported by a grant from the Korean Mental Health Technology R\&D Project, Ministry of Health \& Welfare, Republic of Korea (HM14C2603)

\begin{abstract}
Objectives: This study aimed to investigate the influence of media exposure to children's language development as a part of a cohort study on the progressive influences and risk factors of smartphone exposure to young children. Methods: The participants were 208 children aged 3 to 5 who participated in the prospective cohort study. Children who participated in a survey on media exposure were followed up 6-12 months later and their language abilities were assessed using Receptive \& Expressive Vocabulary Test (REVT) and Preschool Receptive-Expressive Language Scale (PRES). The media exposure times according to age and media types were analyzed through a repeated two-way ANOVA. The influences of the media exposure time on the language development of the children were analyzed through a simple and a stepwise multiple regression analysis. Results: First, total media exposure time was not significantly different by age but the media exposure time was significantly different according to media devices. Television exposure time was the longest, followed by smartphone. Second, total media exposure time negatively influenced children's language development, and the influence of the 3 and 4 years group was larger than the 5 years group. According to media device, the smartphone exposure time negatively influenced on children's language development, followed by television. Conclusion: The results of this study show that the media exposure negatively influenced children's language development, especially younger children and the negative influence was larger with smartphones than other media devices. The results of this study help to identify the influence of media exposure on children's language development and have implications for developing policies against media exposure in childhood.
\end{abstract}

Keywords: Media exposure, Television, Smartphone, Language development, Cohort study
미디어 기기의 급격한 발달로 인해 미디어 이용률이 급격하게 증 가하고 있으며(Lee, Do, \& Oh, 2013), 미디어 기기에 노출되는 시기 도 점차 빨라지고 있다(Lee, Do, et al., 2013; Shin, 2016; Holloway, Green, \& Livingstone, 2013). 미디어 기기에 노출되는 시기가 저연 령화되고, 어린 시기부터 미디어 기기 이용이 증가함에 따라 미디 어 노출이 영유아 발달에 미치는 영향에 대한 관심도 함께 증가하
고 있다.

미디어 기기 노출이 아동 발달에 미치는 영향은 여러 연구자들 에 의해 관심을 받아 왔다. 연구자들 중에는 미디어 기기를 통한 여 러 교육적 자극을 효과적으로 제공하여 아동들의 인지나 언어발달 에 도움이 된다는 견해를 제기하기도 하였으나(Garrison \& Christakis, 2005; Linebarger \& Vaala, 2010) 대체로 영유아의 발달에 부정 
적인 영향을 미친다는 것이 지배적이다(Hinkley et al., 2014; Kang, 2008; Lee, Shin, Chun, Park, \& Chung, 2005). Hinkley 등(2014)은 미디어 매체 노출이 아동 발달에 미치는 영향에 대한 종단적 연구 를 통해 영유아기에 TV나 컴퓨터 등 미디어 매체에 많이 노출될수 록 이후 건강이나 생활에 부정적인 영향이 커지며, 정서나 가족문 제도 1.2-2배 정도 증가하였다고 보고하였다. 국내에서도 아동들이 영상물이나 미디어에 과다노출될수록 사회적 상호작용이나 정서 조절 문제, 공격성, 역기능적 활동수준, 과도한 경직성과 기타 행동 문제를 보였으며(Lee et al., 2005; Lee, Jung, \& Kim, 2015), 산만성 이나 대인관계 문제, 폭력성이 증가하고(Kang, 2008), 지능과 부적 상관이 있었다는(Park \& Park, 1998) 등 발달 전반적으로 부정적 영향이 보고되었다.

미디어 기기나 매체에의 노출이 언어발달에 미치는 영향을 살펴 본 연구들도 대체로 부정적 영향을 보고하였다(Lee et al., 2015; Mendelsohn et al., 2010; Pae \& Cheong, 2015; Tomopoulos et al., 2010; Zimmerman, Christakis, \& Meltzoff, 2007). Zimmerman 등 (2007)은 2 세 이하의 영아 1,008명을 대상으로 미디어 노출과 언어 발달과의 관계를 조사하였는데, 8-16개월 영아들의 경우 하루 DVD 나 비디오 시청 시간이 어휘검사인 Communication Development Index $(\mathrm{CDI})$ 점수와 부적상관을 보였다고 보고하였다. 그러나 부모 와 함께 미디어를 시청한 경우에는 모두 미디어 노출 시간이 CDI 점수와 유의한 상관을 보이지 않았다. Mendelsohn 등(2010)은 253 명의 영아를 대상으로 6 개월에 미디어 노출 정도를 조사한 후 14 개 월이 되었을 때 언어발달 검사를 실시하여 종단적으로 미디어 노출 이 언어발달에 영향을 미치는지 확인하였다. 언어발달은 PLS-4를 활용하여 측정하였는데, 미디어 노출 정도가 언어발달과 부적상관 이 있었다고 보고하였다. Tomopoulos 등(2010)도 비슷하게 259명 의 영아를 대상으로 6 개월에 미디어 노출이 이후 14 개월 언어발달 에 영향을 미치는지를 종단적으로 확인한 결과 미디어 노출 정도 와 언어발달 간의 부적상관을 보고하여 동일한 결과를 보고하였다.

앞에서 소개한 연구들이 대부분 2 세 미만의 일반 영아를 대상으 로 연구한 반면, Chonchaiya와 Pruksananonda (2008)는 15-48개 월 사이의 일반 유아 110 명과 언어지연아동 56 명을 대상으로 연구 하였다. 미디어는 TV 시청 시간만으로 미디어 노출 시간을 측정하 였는데, 언어지연 아동이 일반아동에 비해 하루 평균 텔레비전 시 청 시간이 유의하게 더 많았으며, TV 시청 시간이 언어발달 지연에 영향을 미쳤다고 보고하였다.

국내에서 진행된 연구들도 대체로 국외에서 보고된 것과 유사한 결과를 보고하였다(Lee et al., 2015; Pae \& Cheong, 2015). Lee 등 (2005)은 50 개월 미만의 일반 영유아 120 명과 어린 시기부터 영상
물에 과도하게 노출되었다고 보고된 임상집단 영유아 117 명을 비 교한 결과, 영상물에 과도하게 노출된 영유아의 경우 저조한 의사 소통, 언어발달 지연, 영어 반복 등 특이한 언어 반응이 관찰되었다 고 보고하면서 영상물 과다노출이 언어발달에 부정적 영향을 갖는 다고 보고하였다. Pae와 Cheong (2015)은 6-36개월 영유아 1,452명 을 대상으로 TV와 스마트폰 노출 시간이 언어발달에 미치는 영향 을 조사하였는데, TV 시청시간은 전반적 언어능력에 영향을 미쳤 으나 스마트폰 이용시간은 전반적 언어능력과 표현어휘능력 모두 에 영향을 미치지 않았다고 보고하였다. 5세 유아를 대상으로 미디 어가 미치는 영향을 살펴본 Cho (2016)도 미디어 이용 시간이 증가 할수록 유아의 언어발달에 부정적인 영향을 미치며 이는 다시 긍정 적인 또래상호작용에 부정적으로 작용한다고 보고하였다.

어린 시기의 미디어 노출이 발달에 부정적 영향을 미친다는 결 과들이 보고됨에 따라 여러 나라에서는 어린 시기의 미디어 노출 을 제한하는 정책을 마련하고 있다. 미국소아과학회에서는 만 2 세 영아에게 TV 또는 비디오 시청을 금지하도록 권고하였으며, 일본 역시 미디어 노출에 대한 장기적인 대책을 마련하는 등 국가적 차 원의 연구나 대책을 마련하고 있다(Lee, Jung, Park, \& Chun, 2014). 특히 일본의 경우는 4 년에 걸쳐 일본 전역을 돌아다니면서 아이들 의 실생활을 꼼꼼히 추적하여 텔레비전 및 비디오, 게임, 컴퓨터 등 과 같은 미디어의 노출이 미치는 영향을 보고한 연구(Salazar, 2005) 가 이러한 국가적 정책 마련의 큰 계기가 되었다.

우리나라의 경우는 미디어 노출이 아동 발달에 미치는 영향에 대한 사회적 인식이나 관심이 상대적으로 부족하였으며, 최근에서 야 국가의 지원을 통한 연구가 시도되고 있다(Shin, 2016). 그러나 국외 연구들은 종단적 추적 관찰을 통해 미디어 노출이 특정 시점 만이 아니라 아동 발달에 장기적으로 어떤 영향을 미치는지 보고 해 온 반면, 국내 연구들은 대부분 횡단적 연구를 통해 미디어 노출 의 영향을 보고하였을 뿐이다. 국외에서 이루어진 종단적 추적연 구들은 미디어 노출이 노출된 시점만이 아니라 이후의 시기까지 지속적으로 영향을 미칠 수 있음을 보고하고 있다(Mendelsohn et al., 2010; Tomopoulos et al., 2010; Zimmerman et al., 2007). 이처 럼 장기적 영향을 확인하는 것은 미디어 노출의 영향을 이해하는 데에는 물론 국가적 정책을 수립하는 데 매우 중요한 의미를 가질 것이다.

이 연구는 이러한 배경하에 영유아기의 미디어 기기 노출, 특히 요즘 이용 추세가 증가하고 있는 스마트폰에 대한 노출이 이후 아 동 발달에 미치는 영향을 확인하고자 하는 전향적 코호트 연구의 일환으로 진행되었다. 코호트 연구는 특정 조건의 대상을 일정한 기간 동안 관찰하고, 시간에 따른 경과를 확인함으로써 변수 관계 
를 살펴보는 연구방법(Maxwell \& Satake, 2006)이다. 본 연구는 이 러한 코호트 연구방법을 통해 2-5세의 영유아기에 미디어 노출이 이후 언어발달에 어떠한 영향을 미치는지 확인하는 것을 종단적으 로 확인하고자 하였다. 특히 기존의 국내외 연구들이 특정 연령 집 단을 대상으로 TV 또는 스마트폰과 같이 특정 매체에 국한된 결과 만을 보고하였는데, 본 연구에서는 연령과 미디어 기기 유형을 변 수로 포함하여 미디어 노출의 영향이 연령과 매체 유형에 따라서는 어떻게 달라지는지를 확인하고자 하였다. 본 연구는 영유아 시기의 미디어 기기에의 노출이 언어발달에 미치는 발달적 영향을 확인하 고 나아가 이를 위한 적절한 예방 및 관리대책 수립에 토대가 될 수 있을 것이다.

\section{연구방법}

\section{연구참가자}

보건복지부 정신건강기술개발사업(2014)으로 진행되고 있는 "영유아 스마트폰 노출의 경과 및 위험 요인에 대한 전향적 코호트 연구”의 1차년도에 참가한 3-5세 영유아 400명 중 318명이 연구에 참가하였다. 이 연구 프로젝트는 미디어 노출이 영유아의 발달에 미치는 장기적 영향을 확인하고 이를 위한 예방 및 관리 대책을 수 립하기 위한 목적으로 시도된 것으로, 2-5세 영유아를 대상으로 전 향적 코호트 연구 방법을 통해 총 5 년에 걸쳐 매해 발달 경로를 확 인하도록 계획되었다. 이를 위해 1 차년도에는 영유아 시기의 미디 어 노출 실태를 조사하였으며, 이후 매해 발달 검사를 실시하는데 본 연구는 6 개월에서 1 년 후의 발달 추적 검사에 참여한 영유아를 대상으로 하였다.

1차년도의 미디어 노출 실태 조사는 2015년 9월부터 2016년 7월 까지 고양, 수원, 성남 지역의 아동 청소년 정신건강센터를 중심으 로 영유아 부모 400 명을 대상으로 코호트 연구팀에 의해 진행되었 다. 설문조사가 이루어진 6-12개월 후에 언어평가 참가 신청을 받았 으며, 총 318 명이 평가에 참여하였다. 이 중 언어검사 결과가 완료되 지 않거나 발달지연이 확인된 110 명을 제외한 208 명의 영유아가 최 종적으로 연구참가자로 포함되었다(Figure 1).
분석에 포함된 208명의 참가자 정보와 언어검사 결과는 Tables 1과 2 에 제시하였다. 먼저 참가 영유아의 연령 분포는 3 세 52 명, 4 세 90 명, 5세 66명이었으며, 성별은 여아 108명(51.9\%), 남아 100 명(48.1\%)이 었다. 부모의 학력은 아버지와 어머니 모두 대졸이 186명(89.4\%)으 로 가장 많았으며, 월 소득은 200-400만 원이 96명(46.2\%)으로 가 장 많았고, 400-600만 원, 600 만 원 이상 순이었다. 직업은 아버지 의 경우 사무/기술직 85 명(41.5\%), 관리직/준전문직 37명(18\%), 사 업장근로자 32 명(15.6\%), 자영업자 28 명(13.7\%) 등의 순이었다. 어 머니의 직업은 대다수가 주부였으며(134명, 64.4\%), 사무/기술직 30 명(14.4\%), 전문직/고위관리직 14 명(6.7\%) 등의 순이었다. 가족 유형 으로는 부모와 자녀의 유형이 $86.1 \%$ 로 가장 많았고, 그 다음으로 조부모, 부모, 자녀의 유형이 $11.5 \%$ 로 많았다. 결혼 형태로는 각 연 령 집단 모두 기혼이었으며, 주 양육자 또한 어머니인 것으로 나타 났다(Table 1).

취학전 아동의 수용언어 및 표현언어 발달척도(Preschool Receptive-Expressive Language Scale, PRES; Kim, Sung, \& Lee, 2003)와 수용·표현어휘력검사(Receptive \& Expressive Vocabulary Test, REVT; Kim, Hong, Kim, Jang, \& Lee, 2009)로 언어능력을 검사한 결과, 연구에 참여한 영유아 모두 또래 규준과 비교 시 $-1 \mathrm{SD}$ 와 +2 $\mathrm{SD}$ 사이에 속하였다. PRES에서는 3세의 경우 수용언어연령, 표현 언어연령, 통합언어언령이 각각 $50.87,51.56,51.42$ 개월이었으며, 4 세의 경우 평균 $63.42,60.31,61.63$ 개월, 5 세의 경우 평균 $66.83,63.74$, 65.61개월로 나타났다. REVT에서는 3세의 경우 수용어휘력 점수 는 평균 41.40점, 표현어휘력 점수는 평균 47.44점이었으며, 4세의 경우 수용어휘력 점수와 표현어휘력 점수는 각각 평균 58.10점과 63.73점, 5 세의 경우 수용어휘력 점수는 평균 64.50점, 표현어휘력 점수는 72.24점이었다. 세 연령 집단은 모든 언어검사 결과에서 통 계적으로 유의한 차이를 보였다(Table 2).

\section{연구도구}

미디어 노출 시간 측정 도구

미디어 노출 시간은 코호트 연구 1년차에 실시한 미디어 이용 설 문지 내용 중 미디어 매체 유형별 노출 시간을 묻는 항목의 결과를

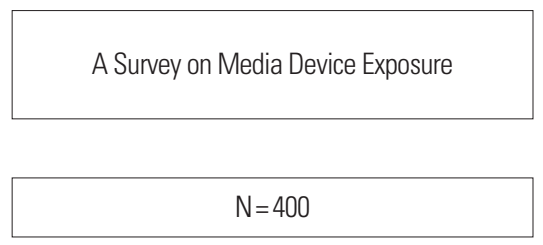

6 months-1 year later

$\rightarrow$
Language assessment

$N=318$

Figure 1. Research process. 
Table 1. Participants' information

\begin{tabular}{|c|c|c|c|c|}
\hline & \multicolumn{4}{|c|}{ Age group (yr;mo) } \\
\hline & $3 ; 0-3 ; 11(\mathrm{~N}=52)$ & $4 ; 0-4 ; 11(\mathrm{~N}=90)$ & $5 ; 0-5 ; 11(\mathrm{~N}=66)$ & Total $(\mathrm{N}=208)$ \\
\hline \multicolumn{5}{|l|}{ Sex of children } \\
\hline Female & $28(53.8)$ & $49(54.4)$ & $31(47.0)$ & $108(51.9)$ \\
\hline Male & $24(46.2)$ & $41(45.6)$ & $35(53.0)$ & $100(48.1)$ \\
\hline \multicolumn{5}{|l|}{ Education level of father } \\
\hline$>$ College & $43(82.7)$ & $83(92.2$ & $60(90.9)$ & $186(89.4)$ \\
\hline High school & $9(17.3)$ & $7(7.8)$ & $5(7.6)$ & $21(10.1)$ \\
\hline$<$ Middle school & $0(.0)$ & $0(.0)$ & $1(1.5)$ & $1(.5)$ \\
\hline \multicolumn{5}{|l|}{ Education level of mother } \\
\hline$>$ College & $45(86.5)$ & $82(91.1)$ & $59(89.4)$ & $186(89.4)$ \\
\hline High school & $7(13.5)$ & $8(8.9)$ & $6(9.1)$ & $21(10.1)$ \\
\hline$<$ Middle school & $0(.0)$ & $0(.0)$ & $1(1.5)$ & $1(.5)$ \\
\hline \multicolumn{5}{|l|}{ Average monthly income (million KRW) } \\
\hline$<1$ & $1(1.9)$ & $1(1.1)$ & $1(1.5)$ & $3(1.4)$ \\
\hline $1-2$ & 2 (3.8) & $3(3.3)$ & $4(6.1)$ & $9(4.3)$ \\
\hline $2-4$ & $29(55.8)$ & $16(47.8)$ & $24(36.4)$ & $96(46.2)$ \\
\hline $4-6$ & $12(23.1)$ & $29(32.2)$ & $22(33.3)$ & $63(30.3)$ \\
\hline$>6$ & $8(15.4)$ & $14(15.6)$ & $15(22.7)$ & $37(17.8)$ \\
\hline \multicolumn{5}{|l|}{ Job of father } \\
\hline Day laborers & $0(.0)$ & $1(1.1)$ & $2(.3)$ & $3(1.5)$ \\
\hline Place of business workers & $12(23.1)$ & $11(12.2)$ & $9(13.6)$ & $32(15.6)$ \\
\hline Self-employed & $5(9.6)$ & $11(12.2)$ & $12(18.2)$ & $28(13.7)$ \\
\hline Office and technical & $21(40.4)$ & $42(46.7)$ & $22(33.3)$ & $85(41.5)$ \\
\hline Management and a semiprofessional & $9(17.3)$ & $13(14.4)$ & $15(22.7)$ & $37(18.0)$ \\
\hline Senior management and professional & $3(5.8)$ & $5(5.6)$ & $4(6.1)$ & $12(5.9)$ \\
\hline Housewife and none & $1(1.9)$ & $1(1.1)$ & $1(1.5)$ & $3(1.4)$ \\
\hline Etc. & $1(1.9)$ & $6(6.6)$ & $1(1.5)$ & $8(3.8)$ \\
\hline \multicolumn{5}{|l|}{ Job of mother } \\
\hline Day laborers & $0(.0)$ & $1(1.1)$ & $0(.0)$ & $1(.5)$ \\
\hline Place of business workers & $2(3.8)$ & $3(3.3)$ & $4(6.1)$ & $9(4.3)$ \\
\hline Self-employed & $2(3.8)$ & $3(3.3)$ & $4(6.1)$ & $9(4.3)$ \\
\hline Office and technical & $7(13.5)$ & $13(14.4)$ & $10(15.2)$ & $30(14.4)$ \\
\hline Management and a semiprofessional & $2(3.8)$ & $0(.0)$ & $2(.3)$ & $4(1.9)$ \\
\hline Senior management and professional & $3(5.8)$ & $8(8.9)$ & $3(4.5)$ & $14(6.7)$ \\
\hline Housewife and none & $36(69.2)$ & $56(62.2)$ & 42 (63.6) & $134(64.4)$ \\
\hline Etc. & $0(.0)$ & $6(6.7)$ & $1(1.5)$ & $7(3.4)$ \\
\hline \multicolumn{5}{|l|}{ Family type } \\
\hline Parents and children & $42(80.8)$ & $79(87.8)$ & $58(87.9)$ & $179(86.1)$ \\
\hline Single parent and children & $1(1.9)$ & $2(2.2)$ & $0(.0)$ & $3(1.4)$ \\
\hline Grandparents and children & $0(.0)$ & $0(.0)$ & $0(.0)$ & $0(.0)$ \\
\hline Grandparents, parents and children & $8(15.4)$ & $8(8.9)$ & $8(12.1)$ & $24(11.5)$ \\
\hline Grandparents, single parent and children & $1(1.9)$ & $1(1.1)$ & $0(.0)$ & $2(1.0)$ \\
\hline \multicolumn{5}{|l|}{ Caregiver } \\
\hline Mother & 50 (96.2) & $85(94.4)$ & 62 (93.9) & $197(64.7)$ \\
\hline Father & $0(.0)$ & $0(.0)$ & $1(1.5)$ & $1(.5)$ \\
\hline Grandparents & $1(1.9)$ & $5(5.6)$ & $3(4.5)$ & $9(4.3)$ \\
\hline Etc. & $1(1.9)$ & $0(.0)$ & $0(.0)$ & $1(.5)$ \\
\hline
\end{tabular}

Values are presented as a number $(\%)$.

$\mathrm{KRW}=$ Korean won. 
Table 2. The results of REVT and PRES of participants

\begin{tabular}{lcccc}
\hline & & Age group & \\
\cline { 2 - 3 } & 3 years $(\mathrm{N}=52)$ & 4 years $(\mathrm{N}=90)$ & 5 years $(\mathrm{N}=66)$ & \\
\hline REVT & & & & \\
Receptive vocabulary & $41.40(14.02)$ & $58.10(14.50)$ & $64.50(11.85)$ & $53.431^{* * *}$ \\
Expressive vocabulary & $47.44(15.79)$ & $63.73(11.50)$ & $72.24(10.51)$ & $58.866^{* * *}$ \\
PRES & & & & $60.972^{* * *}$ \\
RLA & $50.87(7.74)$ & $63.42(8.33)$ & $66.83(8.18)$ & $40.856^{* * *}$ \\
ELA & $51.56(9.56)$ & $60.31(5.86)$ & $63.74(7.43)$ & $59.520^{* * *}$ \\
CLA & $51.42(7.95)$ & $61.63(7.10)$ & $65.61(6.57)$ & \\
\hline
\end{tabular}

Values are presented as mean (SD).

REVT= Receptive \& Expressive Vocabulary Test (Kim, Hong, Kim, Jang, \& Lee, 2009); PRES=Preschool Receptive-Expressive Language Scale (Kim, Sung, \& Lee, 2003); RLA= receptive language age; $E L A=$ expressive language age; $C L A=$ combined language age.

${ }^{* * *} p<.001$.

통해 측정하였다. 이 항목은 TV, 스마트폰, 태블릿 PC, 데스크탑 $\mathrm{PC}$, 기타의 미디어 기기별로 미디어 이용 시간을 5 구간(사용 안 함, ' 1 시간 미만', ‘1-3시간', ‘3-5시간', ‘5시간 이상')의 리커트 척도 형식으로 응답하도록 구성되어 있다. 참고로 미디어 이용 설문지는 코호트 연구팀에서 Lee 등(2005)의 영상매체 실태 설문지를 기반 으로 국내외 스마트폰 노출 척도, 미국소아과학회 자료 등을 참고 하여 구성한 것으로 미디어매체 유형별 노출 시간 외에 미디어 매 체 사용, 미디어 콘텐츠 사용, 스마트폰 사용 상황, 스마트폰 이용 이유, 통제방법 등의 내용을 조사하도록 구성되어 있다. 본 연구에 서는 미디어 매체 노출 현황의 영향만을 조사하므로 이 중 매체 유 형별 노출 시간을 묻는 질문의 결과만을 사용하였다.

\section{언어발달검사}

수용-표현어휘력검사(REVT; Kim et al., 2009)와 취학 전 아동 의 수용언어 및 표현언어 발달 척도(PRES; Kim et al., 2003)를 사용 하였다. REVT는 만 2 세 6 개월의 아동부터 16세 이상의 청소년을 대상으로 수용어휘 능력과 표현어휘 능력을 측정하는 것으로 한 국에서 표준화되어 있는 검사도구이다. PRES 또한 한국에서 표준 화된 검사도구로 2 세에서 6 세 6 개월 사이의 취학 전 아동의 수용언 어 및 표현언어 능력을 검사하며, 문법, 어휘, 발음 등의 영역을 평가 하는 검사이다. 두 검사는 모두 신뢰도와 타당도가 보고되어 있다.

\section{연구절차}

코호트 연구 1 차년도 연구에 참여하였던 영유아 부모를 대상으 로 6 개월에서 1년 후 언어평가 신청을 받았으며, 참가 희망자를 대 상으로 평가일정을 조정하였다. 언어평가는 2016년 8월부터 2017 년 1 월 사이에 수원, 성남, 고양에 위치한 세 지역의 아동.청소년 정 신건강센터 개별 상담실을 이용하여 실시하였다. 언어평가 검사자
로는 아동 언어발달검사를 실시한 경험이 많고 잘 훈련되어있는 언 어병리학 박사과정생 2 인과 석사과정생 4 인이 참여하였다. 모든 검 사는 영유아와 검사자가 일대일 상황으로 진행하였다.

\section{자료측정}

본 연구에서는 미디어 노출이 언어발달에 미치는 영향을 확인하 기 위한 방법으로 회귀분석을 실시하였으며 이를 위하여 리커트 척도를 이용해 범주형으로 응답된 반응의 중앙값(median)을 측정 하여 연속변수로 변환하였다. 범주형 응답 결과를 중앙값을 사용 하여 연속형 변수로 전환하는 방식은 소득분위 조사와 같은 국가 통계나 관련 분야 연구(Han, Shin, \& Song, 2014)를 참조하여 결정 하였다. 본 연구에서 '사용 안 함'은 0 시간, " 1 시간 미만'은 30 분, " $1-3$ 시간'은 120 분, '3-5시간'은 240 분, ‘5시간 이상'을 300 분으로 측정 하였다.

언어검사 결과는 REVT의 경우, 수용어휘 점수와 표현어휘 점수 로 산출하였으며 PRES의 경우, 수용언어연령, 표현언어연령, 통합 언어연령으로 산출하였다.

\section{통계분석}

IBM SPSS Statistics version 21.0 (IBM, Armonk, NY, USA)을 사 용하여 분석하였다. 연령 집단에 따른 미디어 노출 시간을 살펴보 기 위해 연령(3) $\times$ 매체(4)의 반복측정 이원분산분석(repeated twoway ANOVA)을 실시하였다. 또한 미디어 매체 노출이 유아의 언어 발달에 미치는 영향을 살펴보기 위해 전체 노출 시간의 영향은 단 순회귀분석(simple regression analysis)으로, 각 매체 유형별 노출 시간의 영향은 중다회귀분석(multiple regression analysis: stepwise method)을 통해 살펴보았다. 


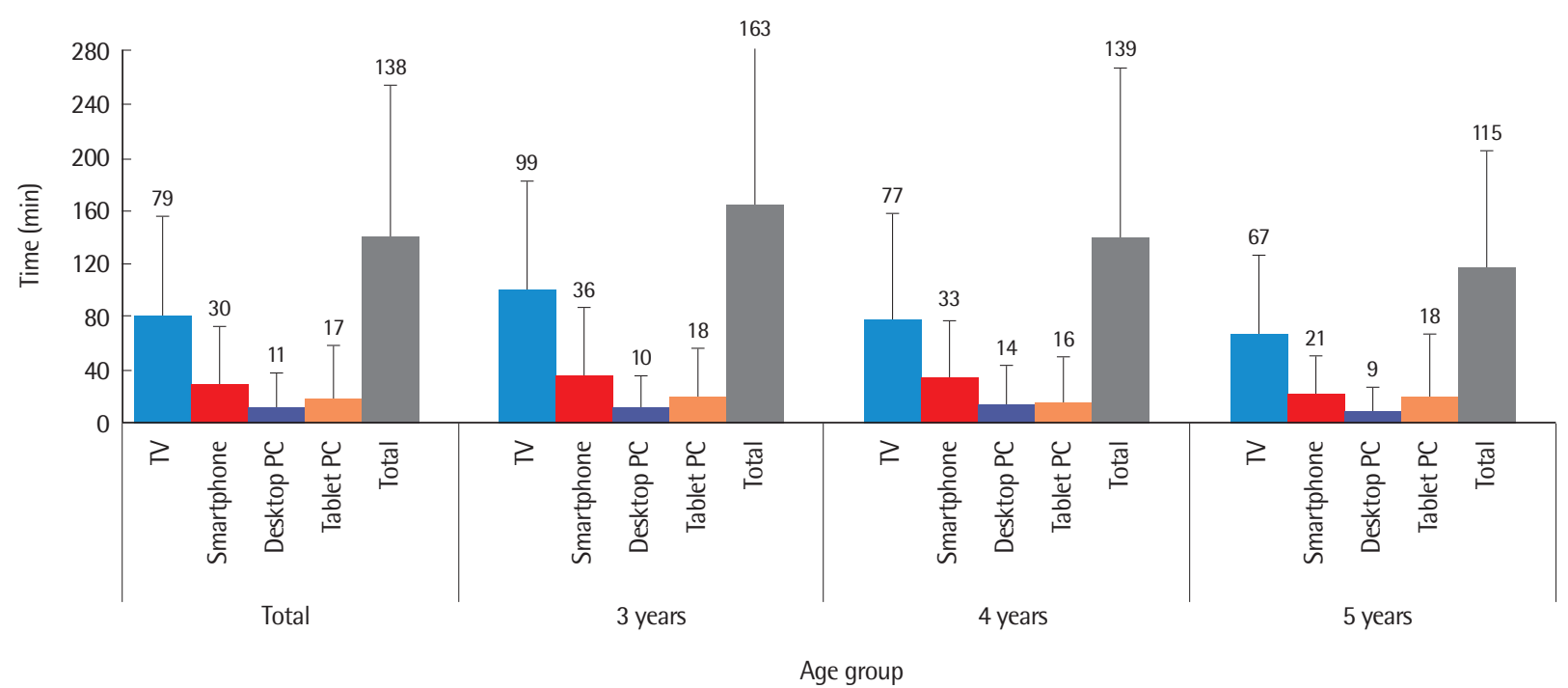

Figure 2. Media exposure time depending on type of media device by age.

\section{연구결과}

\section{연령에 따른 미디어 노출}

영유아 전체 집단의 매체 노출 시간은 138 분이었으며, 연령에 따 라서는 3 세집단이 163 분으로 가장 길었고, 4 세 139 분, 5 세 115 분으 로 연령이 증가함에 따라 감소하는 경향을 보였다. 매체 유형에 따 라서는 TV 시청이 79분으로 가장 길었으며, 스마트폰이 30분, 그리 고 데스크탑 PC와 태블릿 PC 사용 시간이 뒤를 이었다. 미디어 매 체별 이용 시간 경향은 세 연령 집단에서 동일하게 나타났다.

연령 집단과 미디어 매체 유형을 독립변인으로 하여 반복측정된 이원분산분석을 실시한 결과, 미디어 매체 유형에 따른 유의한 주 효과 $\left(F_{(1,205)}=75.266, p<.001\right)$ 가 나타났으나 연령에 따른 주효과 $\left(F_{(1,205)}=2.601, p=.077\right)$ 와 미디어 매체 유형에 따른 연령 간 상호작 용 효과 $\left(F_{(1,205)}=.944, p=.391\right)$ 는 유의하지 않았다. 두 종속표본 $t$ 검정을 통해 미디어 매체 유형에 따른 주효과의 사후분석 결과, TV 와 스마트폰은 다른 매체에 비해 노출 시간이 유의하게 많았으며, 스마트폰은 TV에 비해 노출 시간이 유의하게 적었다(Figure 2).

\section{미디어 노출이 유아의 언어발달에 미치는 영향}

단순회귀분석을 통해 전체 미디어 노출 시간이 언어발달에 미치 는 영향력을 살펴본 결과, 유아 전체에서는 수용어휘력을 $3.8 \%(F=$ $9.105, p<.01)$, 표현어휘력을 $4.9 \%$ ( $F=11.653, p<.01)$, 수용언어연 령 $2.9 \%(F=7.097, p<.01)$, 표현언어연령 $4.2 \%(F=9.964, p<.01)$, 통합언어연령 $4.0 \%(F=9.674, p<.01)$ 부적으로 설명하는 것으로
Table 3. Results of simple regression analysis on language development by total media exposure time

\begin{tabular}{lccccc}
\hline \multirow{2}{*}{ Age group } & \multirow{2}{*}{ Independent variable } & $\begin{array}{c}\text { Dependent } \\
\text { variable }\end{array}$ & $\beta$ & Adj $R^{2}$ & $F$ \\
\hline Total & Total media exposure time & RV & -.206 & .038 & $9.105^{* *}$ \\
& & EV & -.231 & .049 & $11.653^{* *}$ \\
& & RLA & -.182 & .029 & $7.097^{* *}$ \\
& & ELA & -.215 & .042 & $9.964^{* *}$ \\
3 years & CLA & -.212 & .040 & $9.674^{* *}$ \\
4 years & Total media exposure time & RV & -.374 & .123 & $8.126^{* *}$ \\
& Total media exposure time & EV & -.318 & .091 & $9.912^{* *}$ \\
& & RLA & -.269 & .062 & $6.860^{*}$ \\
& & ELA & -.325 & .096 & $10.424^{* *}$ \\
& & CLA & -.280 & .068 & $7.470^{* *}$ \\
5years & Total media exposure time & RLA & .279 & .064 & $5.409^{*}$ \\
\hline
\end{tabular}

$\mathrm{RV}=$ receptive vocabulary; $E V=$ expressive vocabulary; $R L A=$ receptive language age; $E L A=$ expressive language age; $C L A=$ combined language age. ${ }^{*} p<.05,{ }^{* *} p<.01$.

\section{나타났다(Table 3).}

연령별로는 3세에서는 수용어휘력을 $12.3 \%(F=8.126, p<.01), 4$ 세에서는 표현어휘력 9.1\% ( $F=9.912, p<.01)$, 수용언어연령 $6.2 \%$ ( $F=6.860, p<.05)$, 표현언어연령 9.6\% $(F=10.424, p<.01)$, 통합언 어연령 $6.8 \%(F=7.470, p<.01)$ 설명하였으며, 5 세에서는 수용언어 연령만을 6.4\% ( $F=5.409, p<.05)$ 부적으로 설명하였다(Table 3).

미디어 매체에 따른 영향력을 살펴보기 위해 중다회귀분석을 실 시한 결과, 유아 전체에서는 수용어휘력은 스마트폰이 $4.7 \%(F=$ $10.172, p<.01)$ 의 설명력으로 부정적인 영향을 미치며, 표현어휘력 은 스마트폰이 $4.1 \%(F=8.843, p<.01)$, 스마트폰과 TV가 $6.7 \%$ 
Table 4. Multiple regression analysis on language development by exposure time according to media types

\begin{tabular}{llcccc}
\hline Age group & \multicolumn{1}{c}{$\begin{array}{c}\text { Independent } \\
\text { variable }\end{array}$} & $\begin{array}{c}\text { Dependent } \\
\text { variable }\end{array}$ & $\beta$ & Adj $R^{2}$ & $F$ \\
\hline Total & Smartphone & RV & -.217 & .047 & $10.172^{* *}$ \\
& Smartphone & EV & -.203 & .041 & $8.843^{* *}$ \\
& Smartphone+TV & EV & $-.170+-.165$ & .067 & $7.406^{* *}$ \\
& Smartphone & ELA & -.233 & .050 & $11.824^{* *}$ \\
& Smartphone & CLA & -.190 & .031 & $7.710^{* *}$ \\
& Smartphone+TV & CLA & $-.160+-.151$ & .049 & $6.304^{* *}$ \\
& TV years & RLA & -.179 & .027 & $6.789^{*}$ \\
& TV years & RV & -.350 & .105 & $6.993^{*}$ \\
& Smartphone & RV & -.346 & .110 & $11.953^{* *}$ \\
& & EV & -.330 & .099 & $10.781^{* *}$ \\
& & RLA & -.284 & .070 & $7.693^{* *}$ \\
& & ELA & -.394 & .145 & $16.148^{* * *}$ \\
& & CLA & -.308 & .084 & $9.191^{* *}$ \\
\hline
\end{tabular}

$\mathrm{RV}=$ receptive vocabulary; $E \mathrm{~V}=$ expressive vocabulary; $\mathrm{RLA}=$ receptive language age; $E L A=$ expressive language age; $C L A=$ combined language age; $T V=$ television ${ }^{*} p<.05,{ }^{* *} p<.01$.

$(F=7.406, p<.01)$ 부적으로 설명하는 것으로 나타났다. 표현언어 연령은 스마트폰이 $5.0 \%(F=11.824, p<.01)$, 통합언어연령은 스마 트폰이 3.1\% $(F=7.710, p<.01)$, 스마트폰과 TV가 $4.9 \%(F=6.304$, $p<.01)$ 의 설명력으로 부정적인 영향을 미치는 것으로 나타났다 (Table 4).

연령별로는 3세에서 수용어휘력은 TV가 $10.5 \%(F=6.993, p<.05)$ 부적으로 설명하였으며, 4 세에서는 수용어휘력 $(F=11.953, p<.01)$, 표현어휘력 $(F=10.781, p<.01)$, 수용언어연령 $(F=7.693, p<.01)$, 표 현언어연령 $(F=16.148, p<.001)$, 통합언어연령 $(F=9.191, p<.01)$ 을 각각 $11.0 \%, 9.9 \%, 7.0 \%, 14.5 \%, 8.4 \%$ 부적으로 설명하였다(Table 4).

\section{논의 및 결론}

이 연구는 2-5세의 영유아기에 미디어 노출이 언어발달에 미치 는 장기적 영향을 살펴보기 위하여 미디어 노출 실태 조사 후 6개 월에서 1 년 후에 언어발달검사를 추적하여 살펴보았다. 특히, 연령 과 미디어 매체를 변수로 포함하여 미디어 노출의 영향이 연령과 매체 유형에 따라서는 어떻게 달라지는지를 확인하였다.

\section{연령과 매체에 따른 미디어 노출 현황}

먼저 미디어 매체 노출 시간을 조사한 결과, 전체 영유아 집단의 평균 노출 시간은 138 분이었다. 선행연구를 보면, 미디어 노출 시간 은 8-16개월 영아는 0.72시간, 17-24개월은 1.4시간(Zimmerman et al., 2007)에서 2.40시간(Lee, Jung, Park, \& Kim, 2013)까지 다양하 다. 외국에서 보고된 시간은 1 시간 미만에서 150 분을 약간 상회하 는 수준(Mendelsohn et al., 2010; Tomopoulos et al., 2010; Zimmerman et al., 2007)이었던 반면 국내의 경우는 94분에서 2.40시 간(Lee et al., 2013; Pae \& Cheong, 2015) 정도로 약간 더 많았다. 이 처럼 노출 시간이 다양하게 보고된 데에는 주로 양육자 보고를 통 해 노출 시간을 확인하므로 정확한 시간 측정이 어렵다는 점을 고 려할 수 있다. 일반적으로 영유아기 미디어 노출 영향을 살펴본 연 구들은양육자에게 하루 평균 미디어 노출시간을 개방형 질문(open question)이나 리커트 척도 형식으로 응답하게 하여 조사하였다 (Lee et al., 2015; Mendelsohn et al., 2010; Pae \& Cheong, 2015; Tomopoulos et al., 2010; Zimmerman et al., 2007). 두 방법 모두 관찰 을 통해 정확한 시간을 조사하는 것이 아니라 대략적이고 평균적 인 이용시간을 질문하기 때문에 실제 시간과의 편차는 존재할 수 있다. 이와 더불어 조사 대상의 연령이나 조사에 포함한 미디어 매 체의 종류 등에 의해서도 달라질 수 있다는 점도 고려할 수 있다. 대 체로 2 세에서 5 세 사이의 영유아를 대상으로 한 연구들은 국내외 모두 본 연구와 유사하게 2시간을 약간 상회하는 수준으로 2세 미 만의 어린 영아들에 비해 미디어 노출 시간이 더 길었다.

연령에 따라서는 3 세 집단이 163 분으로 가장 길었고, 4 세 139 분, 5 세 115 분으로 2 세 이후의 영유아 집단에서는 나이가 어릴수록 노 출 시간이 길었으며, 연령 증가에 따라 노출 시간이 감소하였다. 그 러나 연령에 따른 유의한 차이는 없었다. 본 연구에서 미디어 노출 은 언어검사가 이루어지기 6 개월에서 12 개월 전에 조사되었기 때 문에 3 세 집단은 2 세 때, 4 세는 3 세 때, 5 세는 4 세 때의 미디어 노출 시간을 의미한다. 통계적으로 유의하지는 않았지만 나이가 어릴수 록 미디어 노출 시간이 상대적으로 긴 이유로는 3세 이후의 영유아 들은 일정 시간을 어린이집이나 유치원에서 지냄에 따라 상대적으 로 미디어 노출의 기회가 제한되는 반면, 나이가 어린 영유아들이 상대적으로 집에서 보내는 시간이 길어 미디어 노출 기회가 상대적 으로 많을 수 있음을 고려할 수 있다. 영유아기의 미디어 노출 현황 을 조사한 Lee 등(2014)은 부모가 영유아에게 영상을 제공하는 동 기를 묻는 질문에서 '아이가 영상을 시청하는 동안 가사일이나 휴 식을 하기 위해서'를 가장 많이 선택하였으며, 그 외 '아이가 재미있 어하니까', '형제들이 시청할 때 자연스럽게 함께 보게 되어서' 등을 주된 이유로 선택하였다. 영유아가 집에서 보내는 시간이 길어질수 록 미디어 기기 접촉 기회가 많아지는 것은 물론 양육자의 가사 활 동이나 양육 부담을 목적으로 미디어에 노출 시키는 경우도 결과 에 어느 정도 영향을 주었을 수 있다.

매체 유형에 따라서는 TV 시청이 79 분으로 가장 길었으며, 스마 
트폰이 30분, 그리고 데스크탑 PC와 태블릿 PC 사용 시간이 뒤를 이었다. TV 노출 시간이 스마트폰을 포함한 다른 매체 노출시간에 비해 유의하게 길었으며, 스마트폰 노출 시간이 데스크탑이나 태블 릿 PC에 비해 유의하게 길었다. 이러한 경향은 세 연령 집단 모두 동 일하게 나타나서 3 세, 4 세, 5세 집단 모두 TV 노출 시간이 99분, 77 분, 67 분으로 가장 길었으며, 다음으로 스마트폰 노출 시간이 36 분, 33 분, 21 분으로 나타났다. 최근 영유아의 스마트폰 이용 시간이 증 가하고 있기는 하나 아직까지는 TV에 노출되는 시간이 두 배에서 세 배 정도 되었다.

종합하면, 영유아들은 하루 평균 139 분 정도 미디어에 노출되었 으며, 나이가 어릴수록 미디어에 노출 시간이 길었다. 미디어 매체 에 따라서는 세 연령 집단 모두 TV에 노출되는 시간이 가장 길었으 며, 다음으로 스마트폰이 차지하였다.

\section{미디어 노출이 언어발달에 미치는 영향}

전체 유아 집단을 대상으로 미디어 노출이 언어발달에 미치는 영향을 살펴보기 위하여 회귀분석을 실시한 결과, 미디어 노출 전체 시간이 REVT의 수용어휘와 표현어휘에 각각 $3.8 \%$ 와 $4.9 \%$ 부적으 로 영향을 미쳤으며, PRES의 수용언어, 표현언어, 통합언어를 각각 $2.9 \%, 4.2 \%, 4.0 \%$ 부적 영향을 미친 것으로 나타났다. 미디어 노출 과 영유아의 언어발달과의 관계를 살펴본 연구들은 대부분 미디어 노출이 언어발달과 부적 상관을 갖거나 부정적인 영향을 미친다고 보고한 바 있다(Lee et al., 2015; Mendelsohn et al., 2010; Pae \&

Cheong, 2015; Tomopoulos et al., 2010; Zimmerman et al., 2007). 본 연구의 결과는 미디어 노출이 노출된 시점만이 아니라 6 개월에 서 1 년 이후의 언어발달에까지도 부정적 영향을 미치는 것을 확인 하였다. 선행연구에서는 미디어 노출이 언어발달에 부정적 영향을 갖는 이유를 주로 미디어 노출이 아동이 다른 사람 간의 상호작용 을 제한하기 때문으로 설명하였다. 간혹 TV나 스마트폰과 같은 미 디어를 함께 보거나 혹은 미디어 기기를 매개로 교육을 제공하는 경우도 있겠지만 대부분의 경우에 아동들은 미디어에 노출될 때 혼자 방치되는 경향이 있다는 것이다(Lee et al., 2015). 따라서 미디 어를 이용하는 시간이 많아질수록 다양한 환경과 접촉하고 상호 작용하면서 언어적 경험이 확장될 기회가 상대적으로 줄어들게 된 다. 초기 언어습득 시기의 어린 연령대에는 양육자와의 양방향적인 사회적 상호작용이 무엇보다 중요하다(Lee \& Seol, 2012). 영아기의 미디어 노출과 이후 언어발달 간의 부적상관을 보고하였던 Zimmerman 등(2007)도 부모와 함께 미디어를 시청한 경우에는 미디 어 노출 시간이 언어발달과 유의한 상관을 보이지 않았다고 보고 하였는데, 이는 언어발달에 대한 미디어 노출 영향이 사회적 상호
작용 기회 제한과 관련될 수 있음을 시사한다. 어린 시기에 혼자 미 디어에 장시간 노출된 아동들에게서 마치 자폐스펙트럼장애와 같 이 사회.정서나 언어발달에서 병리적 증상을 보이는 '비디오 증후 군(Naoki, 2001)'이 관찰되었다는 연구도 상호작용의 중요성을 지 지한다.

연령에 따라서는, 3 세에서는 REVT의 수용어휘(12.3\%)에, 4세에 서는 REVT의 표현어휘(9.1\%)와 PRES의 수용언어(6.2\%), 표현언어 (9.6\%), 통합언어(6.8\%)에, 그리고 5세에서는 PRES의 수용언어(6.4\%) 에 부적 영향력을 갖는 것으로 나타났다. 4 세에서 가장 많은 언어 점수에 영향을 미치는 것으로 나타났으며, 영향을 미치는 정도는 3 세에서 가장 크게 나타났다. 이처럼 나이가 어릴수록 부적 영향력 이 큰 이유는 나이가 어릴수록 미디어에 노출되는 시간이 길었기 때문인 것으로 해석할 수 있다. 본 연구에서 3 세 미디어 노출 시간 이 가장 길었으며, 4 세, 5 세로 갈수록 점차 줄어들었다. 따라서 어린 연령에서 부적 영향이 큰 것은 상대적으로 미디어 이용 시간이 길 었기 때문으로 이해할 수 있다. 이와 더불어 나이가 어릴수록 미디 어 노출의 부정적 영향이 커질 수 있다는 점도 고려할 수 있다. Lee 등(2005)은 나이가 어릴수록 미디어에 과몰입되는 경향이 있다고 하였다. 때문에 같은 시간 미디어에 노출되더라도 그 영향은 커질 수 있다.

매체에 따라서는 유아 전체 집단에서는 스마트폰이 REVT의 수 용어휘 $(4.7 \%)$ 와 표현어휘(4.1\%)에, PRES의 표현언어(5.0\%)와 통합 언어(3.1\%)에 부적 영향을 갖는 것으로 나타나 가장 큰 영향력을 갖는 것으로 나타났으며, 뒤를 이어 TV가 PRES의 수용언어(2.7\%) 와 통합언어(2.2\%)와 REVT의 표현어휘(2.6\%)에 부적 영향력을 갖 는 것으로 나타났다. 미디어 매체가 갖는 영향은 연령 집단에 따라 서도 차이가 있어 3 세 집단에서는 TV 노출 시간이 REVT 수용어 휘(10.5\%)에 부정적 영향을 미치는 것으로 나타난 반면, 4 세 집단 에서는 스마트폰 노출 시간이 REVT의 수용어휘(11.0\%), 표현어휘 (9.9\%), PRES의 수용언어(7.0\%), 표현언어(14.5\%), 통합언어(8.4\%) 에 부정적 영향을 미치는 것으로 나타났다. 본 연구에서 미디어 매 체 노출 시간은 TV가 유의하게 길었던 반면 언어발달에 미치는 영 향력은 스마트폰이 크게 나타났다. 이러한 결과는 TV 노출 시간이 언어발달에 부적 영향을 미쳤으나 스마트폰은 영향을 보이지 않았 다는 Pae와 Cheong (2015)의 결과와는 차이가 있다. 본 연구에서 는 3-5세 영유아를 대상으로 한 반면, Pae와 Cheong (2015)은 더 어린 1-3세 어린 영아들을 대상으로 하였기 때문에 나타난 결과로 이해해 볼 수 있다. 또한 미디어 매체에 따른 노출 시간의 영향도 고 려해 볼 수 있다. 본 연구의 미디어 매체에 따른 노출 시간에서 TV 시청 시간은 3세 99분, 4세 77분으로 큰 차이가 있는 반면, 스마트 
폰은 3 세 36 분, 4 세 33 분으로 차이가 없었다. 이러한 결과는 노출 시간이 비슷할 때에는 스마트폰의 영향력이 커지는 것을 반영하는 것일 수도 있다. Lee 등(2005)은 TV에 비해 스마트폰에 어린 유아 들이 과몰입될 수 있는 경향이 있다고 하였다. 이러한 과몰입은 아 동들의 상호작용을 방해하고, 궁극적으로 언어발달에도 부정적 영향을 미치는 것으로 이해할 수 있다. 또한 Lee와 Lee (2014)는 3-7 세 아동의 부모를 대상으로 언어발달과 디지털 기기 사용에 대한 인식 조사를 실시한 결과, 디지털 사용 기기 중 스마트폰이 가장 많 았으며 부모의 $73.5 \%$ 가 스마트폰이 언어발달에 도움이 되지 않는 다고 인식하였다. 본 연구결과와 마찬가지로 부모들은 언어발달에 스마트폰이 부정적인 영향을 미칠 수 있다고 인식하고 있는 것으로 나타났다.

본 연구를 통해 영유아기에 미디어 노출이 노출 시점만이 아니 라 어느 정도 시간이 경과된 이후까지도 언어발달에 부정적인 영 향을 미치며, 이러한 부정적 영향은 나이가 어릴수록 크게 나타난 다는 사실을 확인하였다. 또한 미디어 매체에 따라서는 어린 나이 에는 노출 시간이 가장 긴 $\mathrm{TV}$ 의 영향이 큰 것으로 나타났으나, 노 출 시간이 비슷할 때에는 과몰입의 영향으로 인해 스마트폰의 영 향이 커진다는 것도 확인하였다. 그리고 이러한 결과를 토대로 아 동들의 언어발달에는 일방적 언어적 자극보다는 상호작용을 매개 로 한 언어자극이 중요함을 논의하였다. 다만 본 연구는 미디어 노 출 시간을 조사한 후 일정 시간 경과 후 언어발달을 평가하기까지 미디어 노출 외에 언어에 영향을 미칠 수 있는 다른 변인들을 통제 하지 않아 이러한 요인이 결과에 미쳤을 영향을 배제할 수 없다. 또 한 부모 응답을 통해 미디어 노출 시간을 확인해야 하기 때문에 응 답의 편의성을 위해 리커트 척도 형식으로 노출 시간을 정확히 측 정하지 못한 점도 연구의 제한점으로 고려된다. 추후연구에서는 관 찰이나 실험적인 연구절차를 통해 미디어 노출 외의 다른 변수를 통제하고 미디어 노출이 미치는 종단적 영향을 살펴보는 것도 의미 가 있을 것이다. 특히 언어발달에 대한 미디어 노출의 부정적 영향 을 주로 상호작용 기회 제한을 중심으로 논의하고 있으므로 영유 아가 미디어 기기에 노출될 때 양육자나 주변 상황을 직접 관찰을 통해 확인해 봄으로써 이러한 논의를 검증해 보는 것도 의미 있을 것이다.

그럼에도 불구하고 본 연구는 설명량이 미미하기는 하였으나 미 디어 노출 시간이 노출되는 시점만이 아니라 6 개월에서 1 년 이후까 지도 언어발달에 부정적 영향을 미쳤다는 사실을 확인하였다는 점 에서는 의의가 있다. 또한 미디어 기기에 따른 영향력을 구분하여 살펴봄으로써 노출 시간이 더 길었던 TV에 비해 스마트폰 노출이 영유아 언어발달에 더 부정적인 영향을 미쳤다는 점을 확인하였던
점도 의미가 있다고 여겨진다.

본 연구결과는 미디어 노출과 관련하여 긍정적 방안을 마련하는 데 도움이 될 것이다. 차후 연구에서는 미디어 노출이 언어발달에 미치는 영향을 공식검사를 활용한 언어검사 결과뿐만 아니라 영유 아의 자발화에서 나타나는 어휘, 구문 등의 영역에 구체적으로 어 떠한 영향을 미쳤는지 확인해 볼 필요가 있을 것이다.

\section{REFERENCES}

Cho, Y. (2016). The impact of young children's media use on peer interactions and the mediating effects of language development. Korean Journal of Child Studies, 37, 53-64.

Chonchaiya, W., \& Pruksananonda, C. (2008). Television viewing associates with delayed language development. Acta Paediatrica, 97, 977-982.

Garrison, M., \& Christakis, D. A. (2005). A teacher in the living room: educational media for babies, toddlers, and preschoolers. Menlo Park, CA: The Henry J. Kaiser Family Foundation.

Han, C., Shin, D., \& Song, H. (2014). Comparison of pneumonia severity scale and pneumonia case payment system classification model in pneumonia. Ilsan: National Health Insurance Service Ilsan Hospital.

Hinkley, T., Verbestel, V., Ahrens, W., Lissner, L., Molnár, D., Moreno, L. A., ... \& Veidebaum, T. (2014). Early childhood electronic media use as a predictor of poorer well-being: a prospective cohort study. JAMA Pediatrics, $168,485-492$.

Holloway, D., Green, L., \& Livingstone, S. (2013). Zero to eight: young children and their internet use. London: EU Kids Online.

Kang, B. J. (2008). An analysis on the behavioral patterns of game over-absorbed children. The Journal of Korea Open Association for Early Childhood Education, 13, 1-21.

Kim, Y. T., Hong, G. H., Kim, K. H., Jang, H. S., \& Lee, J. Y. (2009). Receptive \& expressive vocabulary test (REVT). Seoul: Seoul Community Rehabilitation Center.

Kim, Y. T., Sung, T. J., \& Lee, Y. K. (2003). Preschool receptive-expressive language scale (PRES). Seoul: Seoul Community Rehabilitation Center.

Lee, H. R., \& Lee, S. (2014). Parent survey on the effects of digital instrument on the language development in Korean children. Communication Sciences \& Disorders, 19, 178-190.

Lee, J. R., Do, N. H., \& Oh, Y. J. (2013). Current status and protective measures of young children's exposure to media devices. Seoul: Korea Institute of Child Care and Education. 
Lee, K. S., Jung, S. J., \& Kim, M. S. (2015). The influence of infants' (1-3 years) visual media overindulgence on their general, emotional and social development. The Korean Journal of Developmental Psychology, 28, 117-132.

Lee, K. S., Jung, S. J., Park, J. A., \& Chun, Y. J. (2014). Investigation into current media use by young children aged three and under and their parents' guidance of that use. International Journal of Early Childhood Education, 34, 301-321.

Lee, K. S., Jung, S. J., Park, J. A., \& Kim, M. S. (2013). Media heavy use of infants aged 0-3 years in Korea. Proceedings of the Korean Psychological Association Annual Conference, Daejeon, Korea.

Lee, K. S., Shin, Y. J., Chun, Y. J., Park, J. A., \& Chung, Y. K. (2005). The effects of extreme exposure to mass media on young children's development. The Korean Journal of Developmental Psychology, 18, 75-103.

Lee, Y. K., \& Seol, A. (2012). Maternal communication style of toddlers with developmental language delay during toddler-mother interaction. Korean Journal of Communication \& Disorders, 17, 263-273.

Linebarger, D. L., \& Vaala, S. E. (2010). Screen media and language development in infants and toddlers: an ecological perspective. Developmental Review, 30, 176-202.

Maxwell, D. L., \& Satake, E. (2006). Research and statistical methods in communication sciences and disorders. Boston, MA: Thomson/Delmar Learning.

Mendelsohn, A. L., Brockmeyer, C. A., Dreyer, B. P., Fierman, A. H., Berkule-
Silberman, S. B., \& Tomopoulos, S. (2010). Do verbal interactions with infants during electronic media exposure mitigate adverse impacts on their language development as toddlers? Infant and Child Development, 19, 577593.

Naoki, K. (2001). Television makes autistic children. Seoul: Book Publishing Culture Club.

Pae, S., \& Cheong, Y. G. (2015). Dose media exposure facilitate young children's language development? Korean Journal of Broadcasting and Telecommunication Studies, 29, 67-93.

Park, H., \& Park, M. (1998). Media use by families: correlations with intelligence, problem behavior, and family environments. Korean Journal Child Studies, 19, 3-17

Salazar, C. (2005). What's happening to my child?: a guide for parents of hair pullers. Sacramento, CA: Rophe Press.

Shin, Y. (2016). A prospective cohort study of progression and risk factor of smartphone addiction in toddlers. Proceedings of the Conference on Korea Academy of Mental Health Social Work, Seoul, Korea.

Tomopoulos, S., Dreyer, B. P., Berkule, S., Fierman, A. H., Brockmeyer, C., \& Mendelsohn, A. L. (2010). Infant media exposure and toddler development. Archives of Pediatrics \& Adolescent Medicine, 164, 1105-1111.

Zimmerman, F. J., Christakis, D. A., \& Meltzoff, A. N. (2007). Associations between media viewing and language development in children under age 2 years. The Journal of Pediatrics, 151, 364-368. 


\section{국문초록}

\section{영유아 시기의 미디어 기기 노출이 이후 언어발달에 미치는 영향: 코호트 연구}

이윤경 $\cdot$ 신윤미 $\left.\right|^{2}$ 최지은 3 유희정 $\cdot$ 박은진 ${ }^{5}$

1한림대학교 언어청각학부, ${ }^{2}$ 아주대학교병원 정신건강의학과, ${ }^{3}$ 한림대학교 일반대학원 언어병리청각학과, ${ }^{4}$ 분당서울대학교병원 정신건강의학과, ${ }^{5}$ 인제대학교 일산백병원 정신건강의학과

배경 및 목적: 본 연구는 유아기 스마트폰 노출 경과와 위험 요인에 관한 전향적 코호트 연구의 일환으로 유아의 언어발달에 대한 미디 어 노출의 영향을 확인하는 것을 목표로 하였다. 방법: 코호트 연구에 참여한 3-5세 유아 208명을 대상으로 하였다. 미디어 노출에 대 한 설문 연구에 참여한 유아들을 6-12개월 후 추적하여 REVT와 PRES를 통해 언어능력을 평가하였다. 연령과 미디어 매체 유형에 따 른 미디어 노출 시간을 반복측정 이원분산분석을 통해 분석하였다. 또한 유아의 언어발달에 미치는 미디어 매체 노출 시간의 영향은 단순회귀분석과 중다회귀분석을 통해 살펴보았다. 결과: 첫째, 전체 미디어 노출 시간은 연령 간 유의한 차이가 없었으나, 미디어 노출 시간은 미디어 매체에 따라 유의한 차이가 나타났다. TV노출 시간이 가장 길었고 스마트폰이 그 뒤를 이었다. 둘째, 총 미디어 노출 시 간은 유아의 언어발달에 부정적인 영향을 미쳤으며, 5 세 집단보다 3,4 세 집단에서 더 컸다. 미디어 매체 유형별로 살펴보았을 때 스마트 폰 노출 시간이 유아의 언어발달에 부정적인 영향을 미쳤고, 그 다음으로 TV가 뒤를 이었다. 논의 및 결론: 본 연구 결과는 유아의 언 어 발달, 특히 어린 유아의 경우 미디어 노출이 부정적인 영향을 미치고, 스마트폰이 다른 미디어 매체들보다 부정적인 영향이 더 컸음 을 보여주었다. 본 연구 결과는 유아의 언어발달에 대한 미디어 노출의 영향을 확인하는 데 도움을 주었으며, 유아기의 미디어 노출에 대한 정책개발에 대한 필요성을 보여주었다.

핵심어: 미디어 노출, TV, 스마트폰, 언어발달, 코호트 연구

본 연구는 보건복지부 정신건강기술개발사업의 지원을 받아 수행되었음(No. HM14C2603).

\section{참고문헌}

가타오타 나오키(2001). 텔레비전이자폐아를 만든다. 서울: 도서출판 컬쳐클럽.

강병재(2008). 게임 과몰입 유아의 행동 특성에 관한 분석. 열린유아교육연구, 13, 1-21.

김영태, 성태제, 이윤경(2003). 취학전 아동의 수용언어 및 표현언어 척도(PRES). 서울: 서울장애인종합복지관.

김영태, 홍경훈, 김경희, 장혜성, 이주연(2009). 수용·표현어휘력검사(REVT). 서울: 서울장애인종합복지관.

박혜원, 박문태(1998). 아동의 미디어 이용과 아동의 지능, 문제행동 및 가족환경간의 관계. 아동학회지, 19, 3-17.

배소영, 정연구(2015). 미디어 이용은 영유아 언어발달을 촉진하는가? 한국방송학보, 29, 67- 93.

신윤미(2016). 영유아스마트폰 노출의 경과 및 위험요인.한국정신보건사회복지학회 학술발표논문집.

이경숙, 신의진, 전연진, 박진아, 정유경(2005). 과도한 영상물 노출양육이 영유아의 심리적 발달에 미치는 영향 한국심리학회지: 발달, 18, 75-103.

이경숙, 정석진, 김명식(2015). 1-3 세 영유아 영상물 과몰입이 일반적, 정서사회적 발달에 미치는 영향. 한국심리학회지: 발달, 28, 117-132.

이경숙, 정석진, 김명식, 박진아, 김명식(2013). 국내 0-3세 영유아의 영상물 과몰입 실태조사. 한국심리학회 연차 학술발표 논문집.

이경숙, 정석진, 박진아, 전연진(2014). 0-3세 영유아 영상매체 시청 및 부모의 영유아 자녀 영상매체 시청 지도 행동 실태 조사. 유아교육연구, 34, 301-

321.

이윤경, 설아영(2012). 영유아-어머니 상호작용에서의 언어발달지체 영유아 어머니 의사소통 행동 특성. 언어청각장애연구, 17, 263-273.

이정림, 도남희, 오유정(2013). 영유아의 미디어 매체 노출실태 및 보호대책. 서울: 육아정책연구소.

이희란, 이승복(2014). 아동의 디지털 기기 사용과 언어발달에 관한 부모의 인식 조사. 언어청각장애연구, 19, 178-190.

조윤주(2016). 유아의 미디어 이용이 또래상호작용에 미치는 영향에서 언어발달의 매개효과. 아동학회지, 37, 53-64.

한창훈, 신동교, 송현정(2014). 폐렴에서 폐렴 중증도 척도와 폐렴 포괄수가제 분류 모형과의 진료비 비교. 일산: 국민건강보험 일산병원. 